\title{
The evaluation of neutrophil to lymphocyte ratio and platelet to lymphocyte ratio in anorectal abscess
}

\author{
(1) Çağrı Akalın, M.D.
}

Deparment of General Surgery, Ordu University Training and Research Hospital, Ordu-Turkey

\begin{abstract}
BACKGROUND: Anorectal abscess (ARA) is a commonly observed surgical situation. Our aim is to evaluate neutrophil-lymphocyte ratio (NLR) and platelet lymphocyte ratio (PLR) in ARA.

METHODS: From January 2014 to March 2019, patients diagnosed with ARA were retrospectively analysed, and a patient group was formed. Healthy individuals were included in this study as a control group. The demographic characteristics, completed blood count $(C B C)$ and c-reactive protein (CRP) values of patients were analysed. Localisation of abscess in patients was assessed using computed tomography results. From CBC parameters, white blood count (WBC), NLR and PLR values were identified. The cut-off values for data, sensitivity and specificity were identified using the receiver operating curve (ROC) analyses.

RESULTS: In the patient group, WBC, CRP, NLR and PLR values were identified to be statistically significantly increased $(P<0.00 \mathrm{I})$. When supralevator abscess localisation was compared with other ARA localisations, there was a statistically significant difference for WBC ( $p=0.003$ ), but no statistically significant differences were identified for CRP, NLR and PLR ( $>>0.05)$. ROC analysis found WBC had cut-off value of $9.9910^{3} / \mu \mathrm{L}$ for ARA diagnosis with $95 \%$ sensitivity and $95 \%$ specificity, a CRP had $2.5 \mathrm{mg} / \mathrm{dL}$ cut-off value with $88 \%$ sensitivity and $95 \%$ specificity, NLR had a cut-off of 3.96 with a sensitivity of $82 \%$ and specificity of $95 \%$ and PLR had a cut-off value of I 12.84 with a sensitivity of $71 \%$ and specificity of $68 \%$.
\end{abstract}

CONCLUSION: We believe NLR may be used as a helpful diagnostic marker for ARA diagnosis; however, PLR has low sensitivity and specificity.

Keywords: Anorectal abscess; neutrophil to lymphocyte ratio; platelet to lymphocyte ratio; sensitivity; specificity.

\section{INTRODUCTION}

Anorectal abscess (ARA) is a common surgical condition that requires incision and drainage for treatment. ${ }^{[l]}$ Although ARA usually manifests itself as pain, tenderness and erythema in the rectal region, symptoms, such as fever and malaise, are more prominent with deep abscesses. ${ }^{[2]}$ ARA is associated with increased morbidity and mortality if not treated in the early period. ${ }^{[3]}$ For the diagnosis of ARA, traditional markers, such as white blood cell count (WBC) and C-reactive protein (CRP), as well as assistive imaging methods, such as magnetic resonance imaging and computed tomography $(\mathrm{CT})$, are used. ${ }^{[4,5]}$

Neutrophil to lymphocyte ratio (NLR) and platelet to lympho- cyte ratio (PLR) are inexpensive, non-invasive and easily calculated markers obtained from peripheral blood analysis. In the event of inflammation, the immune response in the systemic circulation is in the form of neutrophilia and lymphopenia, on which the use of NLR and PLR as diagnostic markers is generally based. ${ }^{[6,7]}$ There are studies in which NLR and PLR were used as helpful diagnostic markers for the diagnosis and prognosis of diseases and infections with systemic inflammation. ${ }^{[8,9]}$

The present study aims to research the use of NLR and PLR, accompanied by traditional inflammatory markers, as helpful diagnostic markers for diagnosis of ARA.

Cite this article as: Akalın Ç. The evaluation of neutrophil to lymphocyte ratio and platelet to lymphocyte ratio in anorectal abscess. Ulus Travma Acil Cerrahi Derg 2020;26:887-892.

Address for correspondence: Çağrı Akalın, M.D.

Ordu Üniversitesi Eğitim ve Araştırma Hastanesi, Genel Cerrahi Anabilim Dalı, Ordu, Turkey

Tel: +90 452 - 2250186 / 1566 E-mail: dr.cagriakalin@gmail.com

Ulus Travma Acil Cerrahi Derg 2020;26(6):887-892 DOI: 10.14744/tjtes.2020.0450I Submitted: 30.05.2019 Accepted: 29.03.2020 Online: 26.10.2020

Copyright 2020 Turkish Association of Trauma and Emergency Surgery 


\section{MATERIALS AND METHODS}

Ethical approval for this study was obtained from the Clinical Research Ethics Committee of Ordu University, Faculty of Medicine (Approval number: 2019/75, Date: 09/05/2019). We retrospectively analyzed patients diagnosed with ARA who were operated in two hospitals of Ordu between January 2014 and March 2019. Age, gender, symptoms, duration of symptoms, type of anaesthesia, CT results, complete blood count (CBC) and CRP results were recorded. The exclusion criteria were as follows: patients under 18 years of age, pregnant women, patients with chronic diseases which might affect NLR and PLR (diabetes mellitus, hypertension, inflammatory bowel disease, haematological diseases, coronary artery disease, chronic renal and hepatic failure), patients who were administered medicine which could affect the CBC parameters (intravenous immunoglobulin and thyramazole), patients with malignancy, and patients whose information was inaccessible. The control patients consisted of healthy individuals applying to the general surgery outpatient clinic who did not use any medication. ARA patients were referred to as the patient group and the control patients as the control group. Patient information was obtained from hospital information systems and patient files.

Abdominopelvic CT scan results were used to evaluate ARA localisations, and abscess localisations were classified as submucosal, intersphincteric, ischiorectal and supralevator abscesses.

Laboratory parameters were examined at time of first attendance (before medical and surgical treatment). Venous blood samples for $C B C$ were collected in tubes containing two milliliters $(\mathrm{mL})$ of ethylene-diamine tetra-acetic acid and analysed in an automated haematology analyser device (Sysmex XN-1000, Sysmex Corporation, Kobe, Japan). For CRP, venous blood samples were collected in empty tubes and analysed in a Cobas 6000 autoanalyzer (Roche, Mannheim, Germany). CBC and CRP values were evaluated according to the reference range accepted by the hospital haematology laboratory. WBC value was calculated using the parameters obtained from the CBC analysis. NLR was calculated by dividing the neutrophil count by lymphocyte count, and PLR was obtained by dividing platelet count by lymphocyte count. Patient symptoms were categorised as pain, swelling, fever and general status disorder. Oral intake was stopped in the preoperative period. Patients began analgesic (paracetamol, nonsteroidal anti-inflammatories, opioids), antibiotic (ciprofloxacin $500 \mathrm{mg}+$ metronidazole $500 \mathrm{mg} /$ ampicillin+sulbactam $1.5 \mathrm{~g}$ ) and fluid treatment according to clinical status and surgeon choice. The operations were performed by general surgeons in operating room conditions under local anaesthesia or general anaesthesia. Tests were requested for local anaesthesia according to surgeon choice (haemogram, biochemical, coagulation, ELISA), while preoperative tests were requested for patients who were operated under general anaesthesia (haemogram, biochemical, coagulation, ELISA ( $\mathrm{Hb}$ -
$\mathrm{sAg}$, anti-HCV, anti-HIV), posteroanterior lung radiography and electrocardiogram).

\section{Statistical Analysis}

Data were analysed using SPSS (Statistical Package for Social Sciences) Version 20 for Windows ${ }^{\circledR}$ (Chicago, IL, USA). Whereas the descriptive statistics for continuous variables in our study are expressed as mean, median, standard deviation, minimum and maximum values; they are expressed as number and percentage for categoric variables. The data distribution was evaluated using the Kolmogorov-Smirnov test. Mann-Whitney $U$ and Kruskal-Wallis test were performed for continuous variables. The chi-square test was used to determine the relationship between categoric variables. Receiver operating characteristic (ROC) curve analysis was used to define the optimal cut-offs for NLR and PLR, with specificities, sensitivities, and overall accuracies calculated. P-value $<0.05$ was considered statistically significant.

\section{RESULTS}

Of the 302 patients in this study, 157 (52\%) were in the control group and 145 (48\%) were in the patient group. Of these patients, $104(34.4 \%)$ were female and 198 (65.56\%) were male. Of the 145 patients in the patient group, $44(28 \%)$ were female and I0I (72\%) were male, while of the 157 patients in the control group, 60 were female $(41.4 \%)$ and 97 were male (68.6\%). The mean age was $38.33 \pm 10.01$ years in the study group, $39.77 \pm 10.18$ years in the patient group and $36.99 \pm 9.69$ years in the control group. There was no statistically significant correlation between the groups concerning age and gen$\operatorname{der}(p>0.05)$.

Of the patients, 28 (19.3\%) were operated under local anaesthesia, while $117(80.7 \%)$ were operated under general anaesthesia. When the symptoms of 145 patients were examined, I39 had pain (95.8\%), III had swelling (76.5\%), 71 had fever (48.9\%) and five had disrupted general status (3.4\%). The symptom duration was first 24 hours for 66 patients (45.6\%), 24-48 hours in 34 patients $(23.4 \%), 48-72$ hours in 29 patients $(20 \%)$ and $>72$ hours for 16 patients (II\%). When the symptom durations and laboratory parameters of patients were investigated, there was clinically significant elevation in all parameters with the increase in symptom duration; however, only the CRP value was significantly different $(p<0.05)$. The correlation between duration of symptoms and laboratory parameters of patients is shown in Table I.

The mean platelet count was determined as $245.55 \pm 50.17$ $10^{9} / \mathrm{L}$ in the patient group, and $218.68 \pm 42.2110^{9} / \mathrm{L}$ in the control group. There was a statistically significant difference in WBC, CRP, NLR and PLR values between the groups $(p<0.05)$. WBC, CRP, NLR and PLR values of the patients are given in Table 2. 
In total, perianal abscess was detected in 75 (5I.7\%) patients, intersphincteric abscess in 32 (22.1\%), ischiorectal abscess in 30 (20.7\%), and supralevator abscess in eight (5.5\%). The comparison of supralevator abscess localisation and other ARA localisations revealed a statistically significant difference in WBC $(p<0.05)$, while there was no statistically significant difference in CRP, NLR and PLR ( $>0.05)$. The relationship between WBC, CRP, NLR, PLR and abscess localisations in the patients is given in Table 3 .

The evaluation of the ROC analysis revealed a statistically significant difference in WBC, CRP, NLR and PLR between the groups $(p<0.001)$. The ROC curve, containing the WBC, CRP, NLR and PLR data in the study group, is given in Figure I.
In the ROC analysis, for the diagnosis of ARA, the cut-off value of 9.99 for WBC had $95 \%$ sensitivity and $95 \%$ specificity, the cut-off value of $2.5 \mathrm{mg} / \mathrm{dL}$ for CRP had $88 \%$ sensitivity and 95\% specificity, the value of 3.96 for NLR had $82 \%$ sensitivity and $95 \%$ specificity, and the cut-off value of I 12.84 for PLR had $71 \%$ sensitivity and $68 \%$ specificity. The area under the ROC curve (AUC) values of WBC, CRP, NLR, and PLR for predicting ARA and other data in the ROC curve are demonstrated in Table 4.

\section{DISCUSSION}

For diagnosis of ARA, in addition to physical examination and assisting radiologic investigations, helpful diagnostic markers like WBC and CRP are commonly used. Early di-

Table I. WBC, CRP, NLR and PLR values according to symptom duration

\begin{tabular}{|c|c|c|c|c|c|}
\hline \multirow[t]{2}{*}{ Variables } & \multirow{2}{*}{$\frac{0-24 h(n=66)}{\text { Mean } \pm \text { SD }}$} & \multirow{2}{*}{$\frac{24-48 \text { h }(n=34)}{\text { Mean } \pm S D}$} & \multirow{2}{*}{$\frac{48-72 h(n=29)}{\text { Mean } \pm \text { SD }}$} & \multirow{2}{*}{$\frac{>72 h(n=16)}{\text { Mean } \pm \text { SD }}$} & \multirow[t]{2}{*}{ p-value* } \\
\hline & & & & & \\
\hline WBC $\left(10^{3} / \mu \mathrm{L}\right)$ & $13.19 \pm 1.70$ & $13.28 \pm 2.39$ & $13.95 \pm 4.43$ & $17.47 \pm 7.83$ & 0.13 \\
\hline C-reactive protein (mg/dL) & $3.21 \pm 0.89$ & $4.12 \pm 1.92$ & $5.59 \pm 4.87$ & $10.89 \pm 9.87$ & $<0.001$ \\
\hline NLR & $9.47 \pm 6.03$ & $12.15 \pm 8.09$ & $|4.82 \pm 7.9|$ & $18.58 \pm 10.29$ & 0.19 \\
\hline PLR & $|57.06 \pm 52.2|$ & $168.32 \pm 52.14$ & $|60.62 \pm 5| .47$ & $192.86 \pm 54.09$ & 0.17 \\
\hline
\end{tabular}

*The Kruskal-Wallis test was used, and p-values of less than 0.05 were regarded as statistically significant. h: Hours; WBC: White blood count; CRP: C-reactive protein; NLR: Neutrophil lymphocyte ratio; PLR: Platelet lymphocyte ratio; SD: Standard deviation.

Table 2. WBC, CRP, NLR and PLR values of the patients

\begin{tabular}{|c|c|c|c|}
\hline \multirow[t]{2}{*}{ Variables } & \multirow{2}{*}{$\begin{array}{l}\text { Patient group }(n=\mid 45) \\
\text { Mean } \pm S D(\min -\max )\end{array}$} & \multirow{2}{*}{$\begin{array}{l}\text { Control group }(n=157) \\
\text { Mean } \pm S D(\min -\max )\end{array}$} & \multirow[t]{2}{*}{ p-value* } \\
\hline & & & \\
\hline WBC $\left(10^{3} / \mu \mathrm{L}\right)$ & $13.84 \pm 3.82(2.55-38.61)$ & $7.37 \pm I .69(3.87-|I .4|)$ & $<0.001$ \\
\hline CRP (mg/dL) & $4.7 I \pm 4.85(0.1-35.78)$ & $0.88 \pm 0.77(0.1-4.45)$ & $<0.001$ \\
\hline NLR & I I.47士8.07 (I.22-48.37) & $2.21 \pm 1.03(0.66-8.90)$ & $<0.001$ \\
\hline PLR & $164.36 \pm 52.86(98.50-282.33)$ & $108.13 \pm 38.15(52.7 \mid-264.08)$ & $<0.001$ \\
\hline
\end{tabular}

*The Mann-Whitney $\mathrm{U}$ test was used, and p-values of less than 0.05 were regarded as statistically significant. WBC: White blood count; CRP: C-reactive protein; NLR: Neutrophil lymphocyte ratio; PLR: Platelet lymphocyte ratio; SD: Standard deviation.

Table 3. Abscess localisations and WBC, CRP, NLR and PLR values

\begin{tabular}{|c|c|c|c|c|c|}
\hline \multirow[t]{2}{*}{ Variables } & \multirow{2}{*}{$\frac{\text { Perianal abscess }}{\text { Mean } \pm S D}$} & \multirow{2}{*}{$\frac{\text { Intersphincteric abscess }}{\text { Mean } \pm \text { SD }}$} & \multirow{2}{*}{$\frac{\text { Ischiorectal abscess }}{\text { Mean } \pm \text { SD }}$} & \multirow{2}{*}{$\frac{\text { Supravelator abscess }}{\text { Mean } \pm \text { SD }}$} & \multirow[t]{2}{*}{ p-value* } \\
\hline & & & & & \\
\hline WBC $\left(10^{3} / \mu \mathrm{L}\right)$ & $13.1 \mid \pm 2.87$ & $13.70 \pm 3.15$ & $|4.25 \pm 3.7|$ & $19.53 \pm 8.24$ & 0.003 \\
\hline CRP (mg/dL) & $4.59 \pm 4.94$ & $4.35 \pm 3.31$ & $4.16 \pm 2.38$ & $9.22 \pm 11.31$ & 0.35 \\
\hline NLR & $10.46 \pm 7.88$ & $12.35 \pm 9.08$ & $12.03 \pm 7.22$ & $15.62 \pm 6.57$ & 0.13 \\
\hline PLR & $161.01 \pm 53.35$ & $159.95 \pm 52.88$ & $172.10 \pm 55.86$ & $184.37 \pm 34.05$ & 0.44 \\
\hline
\end{tabular}

*The Kruskal-Wallis test was used, and P values of less than 0.05 were regarded as statistically significant. WBC: White blood count; CRP: C-reactive protein; NLR: Neutrophil lymphocyte ratio; PLR: Platelet lymphocyte ratio; SD: Standard deviation. 


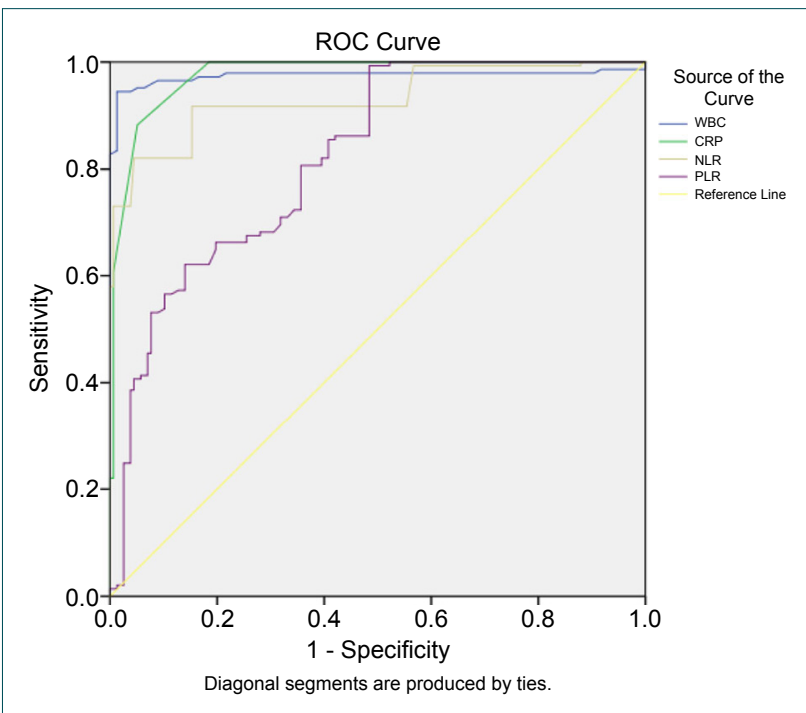

Figure 1. Receiver operating characteristic curve for WBC, CRP, NLR and PLR data in the study group.

agnosis is crucial for ARA since prolonged diagnosis and treatment results in poor prognosis in patients. As a result, helpful diagnostic markers for clinicians guiding ARA diagnosis will provide reduced morbidity and mortality. In this study, the findings showed that NLR has high sensitivity and specificity with WBC and CRP for the diagnosis of ARA, and NLR can be used as a helpful diagnostic marker. PLR has been identified to have low sensitivity and specificity for diagnosis of ARA.

Currently, conditions such as infection and malignancy with high morbidity and mortality rates, have led to the search for new markers. In addition to changes in the neutrophil and lymphocyte counts in response to inflammation, the findings showed that platelets were rich in proinflammatory agents and were able to release active microparticles in case of inflammation. ${ }^{[10]}$ Platelet counts are associated with platelet volume and reactivity, and can be used to reveal the presence of co-morbidities and inflammatory diseases. ${ }^{[11,12]}$ Moreover, recent studies showed that platelets contribute to host defense through granules secreted and their count increases in the case of acute infection. ${ }^{[13,14]}$ Such conditions developing in response to inflammation and infections have paved the way for the use of NLR and PLR as diagnostic markers in recent years.

In the event that surgical intervention is not carried out for ARA, it may result in complications such as perianal sepsis and Fournier's gangrene. ${ }^{[3]}$ Kahramanca et al. ${ }^{[15]}$ investigated the correlation between the number of debridement in Fournier's gangrene, Fournier's gangrene severity index and NLR/PLR, and they found that NLR and PLR were significant in predicting the number of debridement. Although Fournier's gangrene is a complication that arises from ARA, the presence of an infection identical to Fournier's gangrene in ARA and high WBC and CRP values in our study made us think of this context. On the other hand, the findings showed that supralevator abscess was the only one in which WBC was significant among other ARA localisations. We think that this statistical difference that arose from the diagnosis of supralevator abscess was prolonged as it is deeply located. Kahramanca et al. did not find any significant correlation between the severity index of the disease and NLR and PLR, which was similar to our study in which no correlation was found between supralevator abscess and NLR and PLR. Similarly, NLR and PLR were statistically significant for the diagnosis of ARA.

Kaplan et al. ${ }^{[16]}$ investigated the combination of NLR and PLR in patients with pancreatitis in 2018, and they found that the combination was statistically significant when used as a diagnostic marker in pancreatic abscess. In the study conducted by Yıldırım et al., NLR and PLR increased the diagnostic value for tubo-ovarian abscess. ${ }^{[17]}$ In a study of 1067 patients conducted by Kahramanca et al., ${ }^{[18]}$ the findings showed that NLR could be used as a diagnostic marker for the diagnosis of acute appendicitis and might help clinical evaluation of perforated/gangrenous appendicitis. In the study performed by Şentürk et al., ${ }^{[19]}$ the findings showed that NLR was significantly higher in patients with abscess before treatment when control patients were compared to patients with peritonsillar abscess. Moreover, in the study conducted by Seckin et al., ${ }^{[20]}$ they reported that for a NLR cut-off value of $2.67,87 \%$ sensitivity and $82 \%$ specificity could be reached for the diagnosis of pelvic inflammatory disease (PID). However, for the PLR cut-off value of $131.548,65 \%$ sensitivity and $66 \%$ specificity were found in for diagnosis for PID. All

Table 4. Area under the ROC curve of each tested marker

\begin{tabular}{|c|c|c|c|c|c|}
\hline \multirow[t]{2}{*}{ Markers } & \multirow[t]{2}{*}{ AUC } & \multirow[t]{2}{*}{ Standard error } & \multirow[t]{2}{*}{ p-value } & \multicolumn{2}{|c|}{ 95\% Confidence interval } \\
\hline & & & & Lower limit & Upper limit \\
\hline White blood cell $\left(10^{3} / \mu \mathrm{L}\right)$ & 0.975 & 0.012 & $<0.001$ & 0.952 & 0.997 \\
\hline C-reactive protein $(\mathrm{mg} / \mathrm{dL})$ & 0.976 & 0.007 & $<0.001$ & 0.962 & 0.991 \\
\hline Neutrophil to lymphocyte ratio & 0.932 & 0.015 & $<0.001$ & 0.903 & 0.961 \\
\hline Platelet to lymphocyte ratio & 0.822 & 0.023 & $<0.001$ & 0.776 & 0.868 \\
\hline
\end{tabular}

AUC: Area under the receiver operating characteristic curve; $\mu \mathrm{L}:$ Microliter; mg: Miligram, dL: deciliter. 
of these studies commonly investigated the correlation between abscess and NLR/PLR, and the results were similar to those in our study.

There are some limitations in our study. First of all, the retrospective nature of this study and the limited number of patients are among the limitations. Another limitation is the absence of cytokines or other acute phase reactants as inflammatory markers in the study. On the other hand, there are some advantages. In the literature, to our knowledge, there is no study showing the correlation between ARA and NLR and PLR. In addition, we think that the inclusion of ARA by classifying based on localisations in this study is another advantage. In conclusion, we believe NLR may be used as a helpful diagnostic marker to guide clinicians in the diagnosis of ARA, while PLR had low sensitivity and specificity.

\section{Acknowledgements}

I would like to thank Dr. Hakan Peker, Dr. Hüseyin Şahin, Dr. Selim Akçay, Dr. Atila Öztürk, Dr. Hamdi Tütüncü from the General Surgery Department of Centers for providing the patients' medical record and support in accessing patient information.

Ethics Committee Approval: Approved by the local ethics committee. (Approval number: 2019/75, Date: 09/05/2019). Additionally, written institutional permission was obtained from the Ordu Province Health Directorate and hospital administrations.

Peer-review: Internally peer-reviewed.

Conflict of Interest: None declared.

Financial Disclosure: The author declared that this study has received no financial support.

\section{REFERENCES}

1. Billingham RP, Isler JT, Kimmins MH, Nelson JM, Schweitzer J, Murphy MM. The diagnosis and management of common anorectal disorders. Curr Probl Surg 2004;41:586-645. [CrossRef]

2. Abcarian H. Anorectal infection: abscess-fistula. Clin Colon Rectal Surg. 2011;24:14-21. [CrossRef]

3. Yilmazlar T, Ozturk E, Ozguc H, Ercan I, Vuruskan H, Oktay B. Fournier's gangrene: an analysis of 80 patients and a novel scoring system. Tech Coloproctol 2010;14:217-23. [CrossRef]

4. Ulug M, Gedik E, Girgin S, Celen MK, Ayaz C. The evaluation of bacteriology in perianal abscesses of 81 adult patients. Braz J Infect Dis 2010;14:225-9. [CrossRef]

5. Khati NJ, Sondel Lewis N, Frazier AA, Obias V, Zeman RK, Hill MC.
CT of acute perianal abscesses and infected fistulae: a pictorial essay. Emerg Radiol 2015;22:329-35. [CrossRef]

6. Zahorec R. Ratio of neutrophil to lymphocyte counts--rapid and simple parameter of systemic inflammation and stress in critically ill. Bratisl Lek Listy 2001;102:5-14.

7. Shimoyama Y, Umegaki O, Agui T, Kadono N, Minami T. Neutrophil to lymphocyte ratio and platelet to lymphocyte ratio are superior to other inflammation-based prognostic scores in predicting the mortality of patients with gastrointestinal perforation. JA Clin Rep 2017;3:49. [CrossRef]

8. de Jager CP, van Wijk PT, Mathoera RB, de Jongh-Leuvenink J, van der Poll T, Wever PC. Lymphocytopenia and neutrophil-lymphocyte count ratio predict bacteremia better than conventional infection markers in an emergency care unit. Crit Care 2010;14:R192. [CrossRef]

9. Kartal O, Kartal AT. Value of neutrophil to lymphocyte and platelet to lymphocyte ratios in pneumonia. Bratisl Lek Listy 2017;118:513-6.

10. Scherlinger M, Guillotin V, Truchetet ME, Contin-Bordes C, Sisirak V, Duffau P, et al. Systemic lupus erythematosus and systemic sclerosis: All roads lead to platelets. Autoimmun Rev 2018;17:625-35. [CrossRef]

11. Abdel Galil SM, Edrees AM, Ajeeb AK, Aldoobi GS, El-Boshy M, Hussain W. Prognostic significance of platelet count in SLE patients. Platelets 2017;28:203-7. [CrossRef]

12. Lood C, Tydén H, Gullstrand B, Nielsen CT, Heegaard NH, Linge P, Jönsen A, et al. Decreased platelet size is associated with platelet activation and anti-phospholipid syndrome in systemic lupus erythematosus. Rheumatology (Oxford) 2017;56:408-16. [CrossRef]

13. Klinger MH, Jelkmann W. Role of blood platelets in infection and inflammation. J Interferon Cytokine Res 2002;22:913-22. [CrossRef]

14. Rose SR, Petersen NJ, Gardner TJ, Hamill RJ, Trautner BW. Etiology of thrombocytosis in a general medicine population: analysis of 801 cases with emphasis on infectious causes. J Clin Med Res 2012;4:415-23.

15. Kahramanca S, Kaya O, Özgehan G, Irem B, Dural I, Küçükpınar T, et al. Are neutrophil-lymphocyte ratio and platelet-lymphocyte ratio as effective as Fournier's gangrene severity index for predicting the number of debridements in Fourner's gangrene?. Ulus Travma Acil Cerrahi Derg 2014;20:107-12. [CrossRef]

16. Kaplan M, Ates I, Oztas E, Yuksel M, Akpinar MY, Coskun O, et al. A New Marker to Determine Prognosis of Acute Pancreatitis: PLR and NLR Combination. J Med Biochem 2018;37:21-30. [CrossRef]

17. Yildirim M, Turkyilmaz E, Avsar AF. Preoperative Neutrophil-to-Lymphocyte Ratio Has a Better Predictive Capacity in Diagnosing Tubo-Ovarian Abscess. Gynecol Obstet Invest 2015;80:234-9. [CrossRef]

18. Kahramanca S, Ozgehan G, Seker D, Gökce EI, Seker G, Tunç G, et al. Neutrophil-to-lymphocyte ratio as a predictor of acute appendicitis. Ulus Travma Acil Cerrahi Derg 2014;20:19-22. [CrossRef]

19. Şentürk M, Azgın İ, Övet G, Alataş N, Ağırgöl B, Yllmaz E. The role of the mean platelet volume and neutrophil-to-lymphocyte ratio in peritonsillar abscesses. Braz J Otorhinolaryngol 2016;82:662-7. [CrossRef]

20. Seckin KD, Karsli MF, Yucel B, Ozkose B, Yildirim D, Cetin BA, et al. Neutrophil lymphocyte ratio, platelet lymphocyte ratio and mean platelet volume; which one is more predictive in the diagnosis of pelvic inflammatory disease? Gynecol Obstet Reprod Med 2015;21:150-4. 
ORİJINAL ÇALIŞMA - ÖZET

\section{Anorektal apsede nötrofil lenfosit oranı ve trombosit lenfosit oranının değerlendirilmesi Dr. Çağrı Akalın \\ Ordu Üniversitesi Eğitim ve Araştırma Hastanesi, Genel Cerrahi Anabilim Dalı, Ordu}

AMAÇ: Anorektal apse (ARA) yaygın görülen cerrahi bir durumdur. Amacımız ARA'da nötrofil lenfosit oranı (NLO) ve platelet lenfosit oranını (PLO) değerlendirmektir.

GEREÇ VE YÖNTEM: Ocak 20I4-Mart 2019 tarihleri arasında ARA tanılı hastalar geriye dönük olarak analiz edilip hasta grubu oluşturuldu. Kontrol grubu için sağlıklı bireyler çalışmaya dahil edildi. Grupların demografik özellikleri, tam kan sayımı (CBC), C-reaktif protein (CRP) değerleri olarak analiz edildi. Hastaların apse lokalizasyonu için bilgisayarlı tomografı sonuçları değerlendirildi. CBC'teki parametrelerden beyaz küre sayısı (WBC), NLO ve PLO değerleri saptandı. Receiver operating characteristic (ROC) analizi ile verilerin kestirim değerleri, duyarııık ve özgüllüğü saptandı.

BULGULAR: Hasta grubunda WBC, CRP, NLO ve PLO değerleri istatistiksel olarak anlamlı derecede yüksek saptandı ( $p<0.00 \mathrm{I}$ ). Hastaların supralevator apse lokalizasyonu ile diğer ARA lokalizasyonları karşılaştıııldığında WBC'de istatistiksel olarak anlamlı fark saptanırken ( $P=0.003$ ), CRP, NLO ve PLO'da istatistiksel olarak anlamlı fark saptanmadı ( $p>0.05$ ). ROC analizinde, ARA tanısı için, WBC'de $9.9910^{3} / \mu L$ kestirim değerinin \%95 duyarlılık, \%95 özgüllüğe; CRP'de 2.5 mg/dL kestirim değerinin \%88 duyarlılık, \%95 özgüllüğe; NLO'da 3.96 cutoff değerinin \%82 duyarlılık, \%95 özgüllüğe; PLO'da I I 2.84 cutoff değerinin \%7I duyarlılık ve \%68 özgüllüğe sahip olduğu belirlendi.

TARTIŞMA: ARA tanısında NLO'nun tanıya yardımcı bir belirteç olarak kullanılabileceğini fakat PLO'nun ise düşük sensitive ve spesiviteye sahip olduğunu düşünmekteyiz.

Anahtar sözcükler: Anorektal apse; duyarlılık; nötrofil lenfosit oranı; özgüllük; trombosit lenfosit oranı.

Ulus Travma Acil Cerrahi Derg 2020;26(6):887-892 doi: 10.14744/tjtes.2020.0450 I 